1917

Sw 5

Swift

Descriptions of three new species of Megascolecid Earthworms from the Pacific Coast Region of the United States of America. 



\section{DESCRIPTIONS OF THREE NEW SPECIES OF MEGASCOLECID EARTHWORMS FROM THE PACIFIC COAST REGION OF THE UNITED STATES OF AMERICA}

BY

LOLA ERNESTA SWIFT

A. B. Mt. Morris College, 1911.

\section{THESIS}

Submitted in Partial Fulfillment of the Requirements for the

Degree of

MASTER OF ARTS

IN ZOOLOGY

IN

THE GRADUATE SCHOOL

OF THE

UNIVERSITY OF ILLINOIS 
Digitized by the Internet Archive in 2013 


\section{7 \\ Sw5}

\section{U N I V E R S I T Y O F I L L I NOIS}

THE GRADUATE SCHOOL

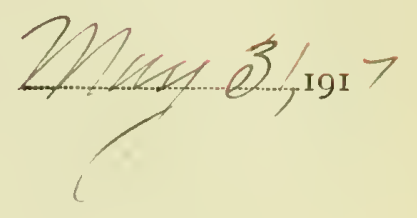

I HEREBY RECOMMEND THAT THE THESIS PREPARED UNDER MY SUPER-

VISION BY ........... Ia Ernesta Srift.

ENTITLED ......... Descriptions of Three NeW Species of IIegascolecid

Earthworms from the Pacific cosst Region of the Inited states of America.

BE ACCEPTED AS FULFILLING THIS PART OF THE REQUIREMENTS FOR THE DEGREE OF .......Mater of Arts.
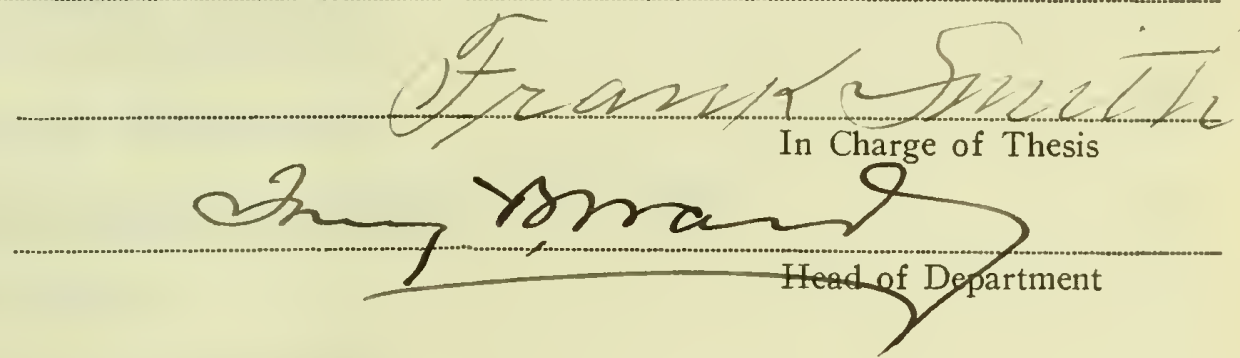

Recommendation concurred in :*

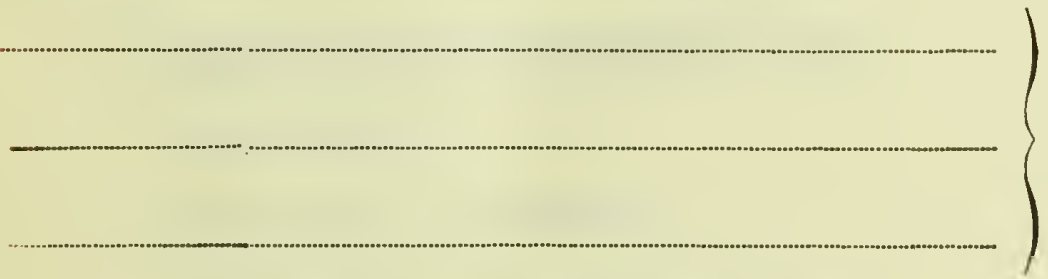

Committee

on

Final Examination*

*Required for doctor's degree but not for master's. 

Table of Contents.

I. Introduction

Te rminology

Material

II. Generic Characters of plutellus

Plutellus oregonensis nov. spec.

Definition

External Characters

Internal Characters

Tabular Arrangement of Important Characters

Discussion of Relationships

III. Generic Characters of Megascolides 16

Megascolides cascadensis nov. spec. 17

Definition $\quad 17$

External Characters 17

Internal Characters $\quad 19$

Megascolides macelfreshi nov. spec. 22

Definition 22

Extermal Characters 22

Internal Characters 24

Megascolides americanus Smith 26

Definition 26

Comparison of Species 28

Discussion of Relationships 31

IV. References to Literature 32 

Table of Contents.

Page

V. Explanation of Plates 33

Abbreviations 33

$\begin{array}{ll}\text { Plate I } & 34\end{array}$

Plate II $\quad 35$

VI. Plates 

Introduction.

The three earthworms described in the following paper are terrestrial forms from the northwestern part of the united states. They belong to the family Megascolecidae; one form in the genus Plutellus and the other two in Megascolides. The discovery of new species of these genera in North America is of interest since the great majority of the representatives are from the Australian and South Eastern Asiatic regions. Of the sixty-four species of Plutellns only four have been found in North America, the majority of the remainder being native to Australia and of the twenty-two of Mesascolides but one has been recorded from North America, the others being mostly from Australia.

\section{Terminology •}

The lack of a uniform terminology used in the description of earthworms necessitates an explanation of the terms used in this paper. Arabic numerals are used to indicate the number of the somite, counting from the anterior end. Externally the somites are separated from each other by intersegmental grooves. The somites may be subdivided by a single secondary groove which produces the biannulate condition, or by two secondary grooves producing the triannulate condition. Internally transverse septa form the divisions between the somites. The intersegmental grooves and the septa for any two adjacent somites are represented by the same formula--for example $5 / 6$, the context showing what is meant. Eight setae per somite are present and are represented for each side by the letters $\underline{a}, \underline{b}, \underline{c}$, and $\underline{\mathrm{d}}$. They are spoken of as closely or widely paired. The term "closely paired" indicates that the distance ab and cd are less than one- 

third the distance bc. If widely paired, these distances are more than one-third bc. The term "prolobic" applied to the prostomium means that it (the prostomium) is small and does not encroach upon the peristomium. Ventral papillae refer to glandular prominences found externally upon the ventral surface.

The term "male pore" is used to designate the opening through which the products of the spermaries and prostate glands pass to the exterior. Sperm sacs, frequently called seminal vesicles, open into the cavities of 10 and $I I$ and store temporarily the sperm cells produced in these somites. Each sperm sac is an evagination of the septal partition into a somite adjacent to the one into which it opens The prostate glands are large contorted, tubular glands usually having close relation with the sperm ducts. They are lacking in many kinds of earthworms, notably in the Iumbricidae. The spermathecae are pouches which lie internally and open to the exterior to receive sperm cells from another individual. They are frequently called seminal receptacles.

Naterial.

The available material for study was scarce so great care was required in preparation and study to keep the specimens in as good condition as possible.

The study of Plutellus oregonensis was made almost entirely from serial sections. The anterior twenty-four somites of the worm had been split in a median sagittal plane and one-half cut into cross sections and the other into sagittal sections.

But one specimen of each of the species of Megascolides macelfreshi and $M$. cascadensis was available. These were prepared for study in the following manner. The anterior ends were split in 

the median sagittal plane. The somites from that part of the right side of each, which included the clitellum, were cut into serial transverse sections. Important facts of structure vere also obtained from a study of the cut surface of the unsectioned half. Small pieces from the posterior parts were prepared for more detailed study of nephridia.

Generic Characters of PIutellus.

The general characteristics of Plutellus as given by Iichaelsen (1900:163) are in substance as follows:- Setae eight per somite. Clitellum beginning with or in front of somite 14 and including 3-9 $2 / 3$ somites. One pair of oviducal pores and occasionally one unpaired oviducal pore. Two to five pair of spermathecal pores, the last pair always on 8/9. One gizzard in somite 5 or 6 or $5-6$, occasionally in 6-7. Nephridia strictly meganephric. Usually two pair of spermaries and sperm ducts in 10 and 11 , or occasionally only one pair in 10 or 11. Sperm vesicles seldom present. Prostates tubular; seldom racemose.

Plutelius oregonensis nov. spec.

Plate I. Figs. 1-10.

Definition- Jength, $77 \mathrm{~mm}$. Diameter, 3-3 1/2 mm. Somites, about 116. Prostomium, prolobic. Setae, widely paired; eight per somite; anterior to clitellum $\underline{a a}: \underline{a b}: \underline{b c:} \underline{c d}:=5: 2: 4: 4$; posterior to clitellum $\underline{a a}: \underline{a b}: \underline{b c}: \underline{c d}=4: 1: 3: 3 ; \underline{d d}$ is a little less than one-half the circumference. Penial setae are present. First dorsal pore in 18/19. Clitellum on 13-18; incomplete ventral1y on 13, 17, and 18; complete on 14-16. Three median ventral papillae are on $7 / 8,8 / 9$, $9 / 10$ and two asymmetrical papillae, one on the left side of $19 / 20$, and one on the right side of 20/21. Nale pores, one pair; each 

opens in a depression which is bordered laterally by a semicircular ridge. Oviducal pores on 14. Spermathecal pores, two pair on $7 / 8$ and $8 / 9$. Septa $7 / 8-11 / 12$ are noticeably thickened. Gizzard in 5; large. Nephridia are strictly meganephric. Spermaries and funnels are in 10 and 11. Sperm ducts, two pair; the two ducts of each side join in 12, extend posteriorly to 18, and join the prostate duct. Sperm sacs, one pair in each of somites 11 and 12 . Ovaries and oviducal funnels in 13. There is a pair of spermathecae in each of somites 8 and 9 ; each with a short thick diverticulum.

The specimens used for study are in the collection of Professor Frank Smith, Urbana, Illinois. Two worms, one mature and one immature were collected by F. M. McElfresh in April 1901 and sent to Professor Smith. They were found in the Cascade Mountains in the bottom lands along the Hary's River. The region was very heavily wooded and subject to overflow during parts of the year. The altitude of Mary's River is between 4000 and 6000 feet.

\section{External Characters.}

No record was kept of the color of the living specimens. The mature worm is small having a length of $77 \mathrm{~mm}$. and a diameter of 3-3 I/2 mm. There are 116 somites. The immature specimen, although containing the same number of somites (116) has a length of but 60 $\mathrm{mm}$. and a diameter of $2 \mathrm{l} / 2-3 \mathrm{~mm}$. The first five somites are uniannulate, 6 and 7 are biannulate, and $8-12$ are triannulate. The lining of the buccal sac may be everted as is shown in the immature specimen which was preserved in this condition. The prostomium is prolobic and shows no indication of a division of the first somite. Setae- There are eight setae per somite except on the first and last and they are widely paired. Setae a and b are longer 

than $\underline{c}$ and $\underline{a}$ and all are slightly curved. The ventral setae anterior to the clitellum are farther apart than those posterior to the clitellum. The setal formula anterior to the clitellum is; $2 a: a b:$ $\underline{\mathrm{bc}}: \underline{\mathrm{cd}}=5: 2: 4: 4$. Posterior to the clitellum the formula is aa: $\underline{a b}$ : $\underline{\mathrm{bc}}: \underline{\mathrm{cd}}=4: 1: 3: 3 . \quad \underline{\mathrm{dd}}$ is a little less than one-half the circumference The setae on somite 18 are somewhat modified. In the place of a and $\underline{b}$, on each side there are present two larger, stronger, slightIy curved setae, located in the position of $\underline{b}$, just mesad of the prostate pore and so close to it that they appear to project through the prostate pore. Setae $\mathrm{c}$ and $\mathrm{d}$ retain their normal positions on this somite. The penial setae are $.23 \mathrm{~mm}$. in length and .042 $\mathrm{mm}$. in diameter at the widest part and are slightly curved near the inner ends. They gradually taper toward the outer extremity and end in a rather blunt point. (Fig. 1.) The central part of the seta is finely sculptured and has the appearance of being spirally wound by a finely fringed band. The two extremities are smooth.

Clitellum- The clitellum is strongly thickened and includes 13-18. It is complete on somites 14-16 but is thicker dorsally and laterally than ventrally. On somites 13, 17, and 18 the clitellum is incomplete except for a slight ventral thickening of the posterior part of 13 and the anterior part of 17 .

Dorsal Pores- The first dorsal pore is in $18 / 19$.

Nephridial Pores- The nephridial pores are paired in each of the intersegmental furrows beginring with the first. They are irregularly disposed and they often do not correspond exactly on the two sides of the same somite. In somites 2-10 the pores are at the same level of the somite. Posterior to 10 there is no regularity in the level at which each pair of pores open to the exterior. Some 

lie in a line with or just dorsad of $\underline{d}$. while others lie between $\underline{b}$ and $\underline{\mathrm{c}}$ but nearer to $\underline{\mathrm{c}}$.

Male Pores- There are two male pores arranged in a pair on 18. Each pore opens in a depression bordered by a semicircular elevation which is concave medially.

Oviducal Pores- The oviducal pores are paired on 14 and open a little mesad of a almost midway of the somite antero-posteriorly.

Spermathecal Pores- Two pair of small spermathecal pores open on a line just laterad of $\underline{b}$ in $7 / 8$ and $8 / 9$ respectively.

Ventral Papillae- There are three median ventral papillae in the form of small glandular areas in $7 / 8,8 / 9$ and $9 / 10$. There is a ventral papilla on the left side of $19 / 20$ and one on the right side of 20/21. Each in on a level with ab of that side.

Internal Characters.

Septa- The first septum noticeable in the sections is that lying between somites 5 and 6 . This septum and the following one are very thin. The septa $7 / 8$ and $12 / 13$ are slightly thickened and $8 / 9-11 / 12$ are noticeably thickened. The septa posterior to $12 / 13$ are all thin. The middle portions of septa $5 / 5-7 / 8$ are pusined out of place to such an extent that each lies in the region of somite 8. Septa $16 / 17$ and $17 / 18$ are pished sliginty forward $b_{y}$ the large prostate glanas in 18 .

Alimentary mact- The alimentary tract begins with a buccal cavity which is eversible. Following this is the pharynx which has a dorsally thickened wall. The esophagus begins in 3 and extends back to the fourth somite as a constricted tube. It expands in 4 into a thin walled cavity which fills the greater part of this 

somite. Between this region and that directly behind is a deep constriction of the wall which leaves but a very narrow passageway between the two. This opens directly into a large extremely muscular walled gizzard which lies in 5 but is so large that it fills the greater part of 5-8, pushing the septa posteriorly into 8 . In $8-11$ the esophagus is very narrow. It widens out in 12 and 13 and is again constricted in 14. From 15 posteriorly, it is gradually enlarged to 18 where it joins the intestine. The intestine is large and sacculated dorsally and laterally. A typhlosole is slightly developed.

Vascular System- (Figs. 4, 5, 6.) This system includes two vessels which extend from the anterior to the posterior ends of the body, these are the dorsal and the ventral or supraneural vessels. Besides these there is a pair of laterals which extend from the 5 th to the llth somites where they join a plexus of vessels in the wall of the alimentary tract. This plexus begins in the middle of 10 and extends as far as sections were studied. Three pair of dorsal hearts connect the dorsal and ventral vessels in somites 7,8 and 9. Four pair of intestinal hearts lie in somites $10-13$ and connect the ventral vessel with the intestinal plexus. A pair of slender branches connect each pair of intestinal hearts with the dorsal vessel.

The dorsal vesiel is single and lies in a median position dorsad of the alimentary tract. ( 1 ig. 4,5,6qvivear the anterior end in 3. the vessel breaks up into four or more minute branches which extend anteriorly. In 5 there are two pair of branches of which the anterior one completely encircles the alimentary tract and gives off three branches on each side. (Fig. $6 \mathrm{cr}$. ) of the se one pair of branches are small and extend anteriorly in a lateral position. 

The second pair (Fig.4,6 I V ) form large lateral vessels which become smaller and more ventral in position as they extend posteriorly. They join the intestinal plexus in 11. The third pair of branches extend dorsally for sorne distance. The posterior pair of branches from the dorsal vessel in 5 are very small and extend to the gizzard. There is a pair of branches, similar to the last mentioned, but larger in size in 6 which also extend to the gizzard. In 7,8 and 9 , the dorsal vessel is connected with the ventral vessel by one pair of dorsal hearts. In 10-13 the diameter of the dorsal vessel is greater than it is more anteriorly and one pair of very small branches in each somite connects this vessel with the intestinal hearts. (Figs. $5,6, i \mathrm{~h} d$ ) In each of the following somites (which were studied) a pair of small dorso-intestinal branches connects the dorsal vessel with the intestinal plexus. (Fig. 6.d.i) From 14-19 the dorsal vessel is moniliform due to constriction by the septa through which it passes.

The ventral vessel lies in a median position just above the nerve cord in the anterior sonites but posteriorly it assumes a more dorsal position under the alimentary canal. (Fig. $4,5,6, v \nabla$ ) In 4 the vessel divides into two branches which extend anteriorly for a short distance then dorsally lying directly under the esophageal commissures. In each of somites 4 to 10 , at least one pair of branches are given off to the septa and body wall. (Figs. $4,6, v t$ ) There are other branches in some of the somites but these were not worked out in detail.

The dorsal hearts in 7-9 are small and show indications of valvular constrictions (Figs. 4,6, d h ) The intestinal hearts in 10-13 are much larger and more distinctly constricted than the 

dorsal hearts. (Figs. 5,6, i h) They connect the ventral vessel with the intestinal plexus, joining the plexus in the mid-dorsal line.

The intestinal blood system is rather complicated. It lies imbedded within the outer wall of the intestine and is composed of a network of vessels. In somites $10-15$ (Fig. 6 i p) the plexus is represented in diagram with the outer intestinal wall removed. The longitudinal vessels are numerous and vary in size from very small to quite large. (Figs. 5,6,1 v p ) They are connected very closely and irregularly by transverse vessels (Figs. 5,6,t $\vee \mathrm{p}$ ) In many places the component vessels are more or less fused while in other regions the net work is quite distinct.

The gizzard in 5 and the esophagus in 6-8 are well provided on their outer surface with small blood vessels.

Excretory System- The excretory system consists of one pair of large meganephridia in each somite with the exception of the first and last. The nephridia in 2, 3 and 4 are larger than those found in the following somites and each one connects with a straight duct which opens into a pore to the exterior. The ducts which open in line with d or dorsad to such a line are longer than those which open between seta lines $\underline{b}$ and $\underline{c}$. The ducts lie free in the body cavity for some distance before entering the body wall. After entering the wall they may open almost directly to the exterior or may extend for a considerable distance in the body vall before opening to the exterior. In some forms which have a variable arrangement of nephridial openings the point at which the ducts enter the body wall is always on a straight line. This is not the case in Plutellus oregonensis, the points of entrence into the wall are as variable as the openings themselves. 

Spermaries and Sperm Duots- There is one pair of spermaries in each of somites 10 and 11 . They are located in the ventral anterior part of the somite and lie free except at the point of attachment to the anterior septum. They are racemose in structure. Posterior to the spermaries in 10 and $I I$ is a pair of large ciliated spermiducal funnels which narrow into a pair of ducts and pass through the posterior septa of these somites. The ducts of either side are inbedded in the epithelium of the body wall, in a ventro-lateral position and join in 12, from which point they extend posteriorly to 18. Here the spern ducts join the prostate ducts at their point of union with the prostate gland.

Prostate Glands- The prostate glands are one pair of tubulare contorted organs in somite 18.

Sperm Sacs- Two pair of large lobed sperm sacs are prominent, in somites 11 and 12. They are attached to the anterior septa of the somites in which they lie and occupy the anterior half of these. In addition to the spern sacs a mass of loose spern cells is present in 11. Somite 10 contains a mass of sperm cells but no sperm sacs.

Ovaries and Oviducts- One pair of large, rather deeply lobed ovaries are attached to the anterior septum of 13 near the ventral body wall. A pair of ciliated oviducal funnels lie in the ventral posterior part of the somite. They connect with the oviducts and pass through the septa to open to the exterior in 14.

Spermathecae and Ducts- There is one pair of spermatiecae in each of somites 8 and 9. They are similar in size and shape but differ in their position in the somites. The anterior pair in 8 are in an upright position with the long axis inclined slightly posterior- 

Iy from the vertical while the second pair in 9 have the long axis almost horizontal in the somite. These positions are probably not characteristic. The following description of the spermathecae will apply to both pair. They are fair sized organs filling about onethird of the somites in which they lie. They are made up of three parts, the large oval ampulla, the smaller blunt diverticulum and the short thick duct. (Figs. $7,8,9,10$ ) The thin walled ampulla is joined at the base with the thick walled diverticulum by a very short connection between the two parts. The lower thick walled diverticulum has in its dorsal part, two lateral evaginations and an anterior one. (Figs. 9,10) These three evaginations are small and have a direct connection with each other internally. The sperm cells are lodged in the cavities of these evaginations.

Tubular Arrangement of Important Characters.

A comparison of plutellus oregonensis with other species of the genus shows a close relationship with but two species. These are

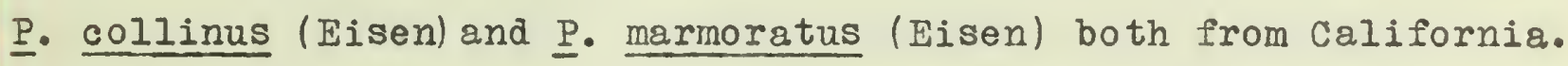
originally these two species and the variety $P$. marnoratus papillifer (Eisen) were described (Eisen 1894: 41-56 and 1900: 163-165) as three varieties of the same species under the name Argilophilus marmoratus but were later referred by Michaelsen (1900: 166, 167) to Plutellus, and $\underline{P}$. collinus recognized as a distinct species.

Characters. Plutelius

oregonensis

Iength

Diameter

Prostomium Prolobic
$77 \mathrm{~mm}$.

3-3 $1 / 2 \mathrm{~mm}$.
P. marmoratus

$\underline{\text { P. }}$ collinus
38-152 mm.

6-9 $\mathrm{mm}$.

Epilobic $1 / 2-3 / 3$
Epilobic dividing somite, . 



\section{Characters Plutellus oregonensis}

\section{P. narmoratus $\quad \underline{P}$. collinus}

$1 / 2-9 / 10$ of distance.

Setre

Eight per somite Eight per somite, widely paired; widely paired;

Eight per somite, widely paired. a a $>\underline{a b}\langle\underline{b c}=\underline{c d} . \quad \underline{a} a>\underline{a b}<\underline{b c}<\underline{c d}$.

Penial setae Slightly curved strongly curved and taper grad- (sickle-like). ually toward the The point is outer extremity. sharp and curved. The middle part A short distance is sculptured, back of the tip flat scales, toothed and has the the surface is appearance of covered with being spirally wound by a numerous slender spines, which are Fig. 2.

fringed band. rather closely Fig. 1. distributed. Fig. 3.

Clitellum Incomplete on Incomplete on $3 / 4$ Incomplete on 13-18. somites 13,17 12-18. and 18; complete on somites 1416.

Dorsal Begin in 18/19 Lacking. Lacking. pores Male pores One pair of One pair of One pair on 18 on openings on 18, openings on a Iunar papillae which 

Characters Plutellus

oregonensis

on a line with

b. in a de-

pression border-

circular elevat-

ion, concave

medially. ed by a semi-

P. marmoratus $\quad$ P. collinus

line with b on 18 are somewhat deon elevated papil- pressed and are lae which are sur- each encircled by a rounded by circular continuous oval depressions enridge. The two ridges are connectcroaching on the two adjoining somites. Outside the ed by a median elevated longitudinal depression is a band.

senicircular ridge

which is concave medially.

Ventral Three median Arrangement varNever paired. Loiable. There may cated in a median be from two to line with the long lae in $7 / 8$, $8 / 9$ and $9 / 10$. five pair of interaxis of the body.

One single pa- segmental papillae pilla in 19/20, with occasionally on the left side one or two papilof the body and lae asymmetricalone in $20 / 21$ on $1 y$ placed. the right side. Each of the latter lies on a level with $a b$ of that side. 



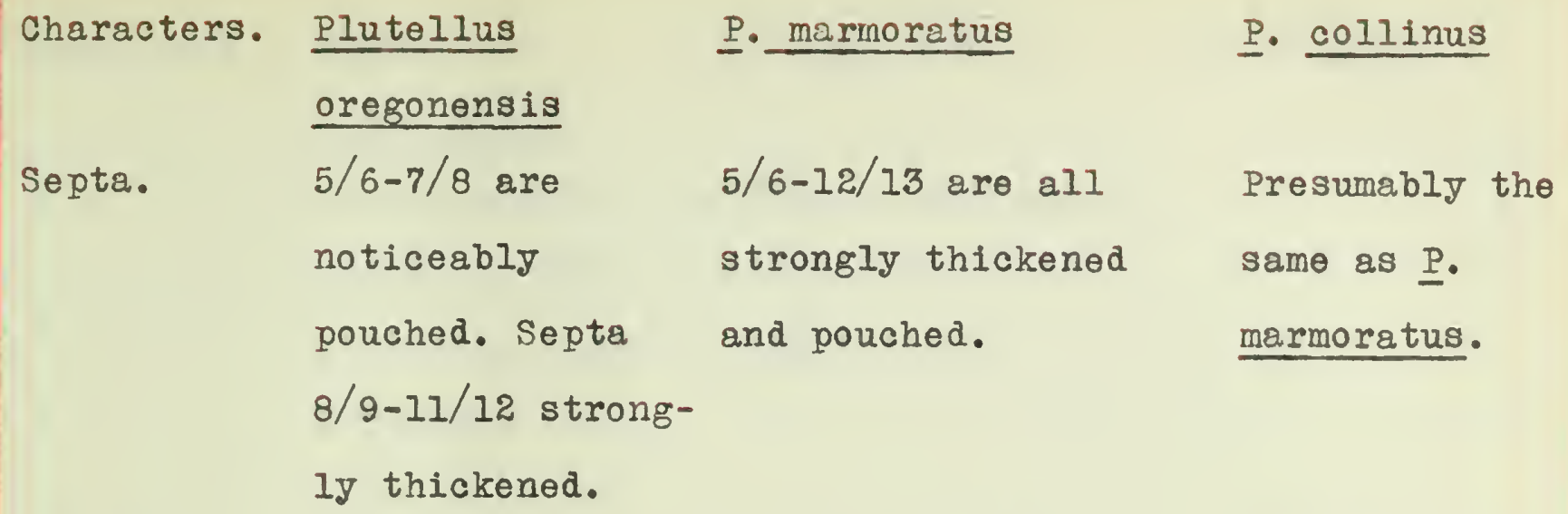

Hearts.

Three pair of

Three pair of stout

dorsal hearts in oblong thrice con-

Same as in $\underline{\underline{P}}$.

7-9. They connect tracted and sac-

the dorsal and like hearts in 10-

ventral vessels. 12 and two smaller

Four pair of in- pair in 13-14 con-

testinal hearts nect the dorsal

in 10-13 connect and ventral vessel.

the ventral vessel

with the intestin-

al plexus.

Nephridia Maganephric.

Begin in somite

Maganephric.

Begin in somite

Same as in $\underline{\text { P. }}$

marmoratus.

marmoratus.
2. The first 2. First five

three pair are or six pair

larger than the larger than the

following.

following.

Sperm

One pair in each one pair in each

sacs.

of somites 11 and of somites 10, 11

12. They occupy and 12. Very large,

about one-half extending far back. 



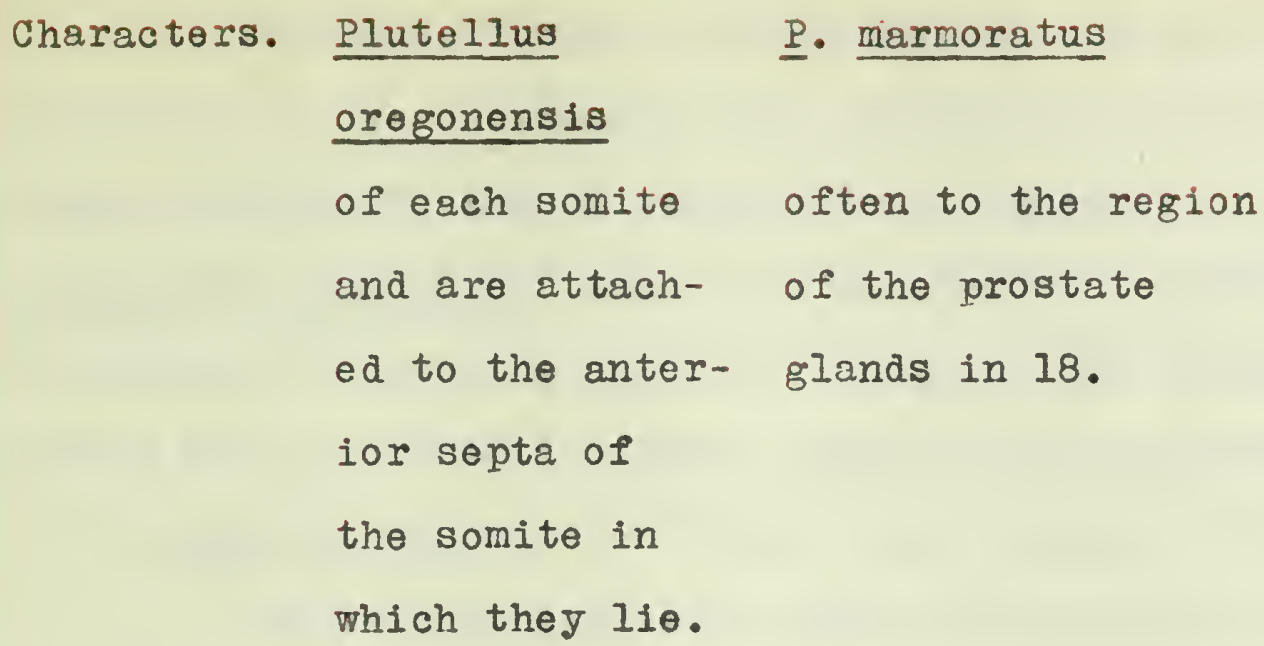

Spermathe- One pair in each one pair in each cae. of somites 8 and of somites 8 and 9 occupying about 9 , occupying one-third of the from one-half to somites in which three-fourths of they lie. A the somites in short thick which they lie. diverticulum is Diverticula are present attached lacking. near the basal part of each spermatheca.

Habitat.

In heavily In rich soils, wooded areas subject to wet, soggy places and manure piles.
Same as in $\underline{P}$. marmoratus.

overflow. 

Discussion of Relationships.

The main points of difference in the species compared, as indicated by the tabulation are: the relation of the clitellum; shape and sculpturing of penial setae; presence of dorsal pores in Plutellus oregonensig; shape and position of genital papillae; arrangement of ventral papillae; position and thickening of septa; number and location of hearts; presence of spermathecal diverticula in $\underline{P}$. oregonensis; and the number and location of the sperm sacs.

The differences seem sufficient to require the recognition of a distinct species for the Cascade worm.

An examination of the article on Argilophilus (Eisen 1894: 48; Figs. $86 \mathrm{~A}$ and $\mathrm{B})$ reveals contradictory statements concerning the position of the gizzard which Eisen describes as 1ying in 6 and he also figures it in 6 , but at the end of the same paper in a comparison of Argilophilus vith plutelius he states that the gizzard in Argilophilus is in 5. The conflicting statements led the writer to examine sections of $\underline{P}$. marmoratus papillifer in the collection of Professor Frank Smith, in which the gizzard is found to be in 5 . In this respect it corresponds with $\underline{P}$. oregonensis.

Generic Characters of Megascolides.

The genus Megascolides as defined by Michaelsen (1900:182) is in substance as follows: Setae, eight per somite. Clitellum begins anterior to 14 or 16 (?) and includes $6-91 / 3$ somites. oviducal pores, one pair on 14. Spermathecal pores, two to five pair; the last pair on 8/9. One gizzard in 5 or 6 or 5-6. Hephridia diffuse; in the posterior part of the body a pair of meganephridia are aditional in each somite. Prostates tubular (seldom racemose). 



\section{Megascolides cascadensis nov. spec. \\ Plate II. Tigs. 11, 14, 15, 17 .}

Definition- Length, $185 \mathrm{~mm}$. Diameter, 5-7 mm. Somites, about 275. Prostomium, slightly developed, prolobic (?). Setae, eight per somite; widely paired; $a a: a b: \underline{b c}: \underline{c d}=8: 2: 4: 6$; dd is about $2 / 3$ the circumference. Penial setae are present. Dorsal pores in post clitellar region. Clitellum 13-20 (8 somites); incomplete ventrally. Ventral papillae, paired on $15 / 16,16 / 17,19 / 20,20 / 21$. Male pores on 18; each in a deep depression. Oviducal pores on 14. Spermathecal pores on $7 / 8$ and $8 / 9$; conspicuous. Septa $6 / 7-11 / 12$ much thickened, 12/13 less thickened. Gizzard large in 5. Nephridia plectonephric. Spermaries, two pair, in 10 and 11. sperm sacs, two pair, in 11 and 12. Ovaries, one pair in 13. Spermathecae, two pair in 8 and 9 .

A single alcoholic specimen was available for study. It was sent to Professor Frank Smith by Mr. F. M. McElfresh in the fall of 1899. It came from the Cascade Range in Oregon. No data concerning the living specimen was recorded.

External Characters.

The color of the living worm is not known. The length of the preserved specimen is about $185 \mathrm{~mm}$. and it has a diameter of 7 $\mathrm{mm}$. in the anterior part of the body and from 5-6 $\mathrm{mm}$. in the posterior part. There are about 275 somites in the body. Somites 1-5 are biannulate and 6-12 are triannulate but not deeply indented. The clitellum on 13-20 is irregularly, but not deeply grooved. The post clitellar somites are faintly grooved. The prostomium is very indistinct in the preserved specimen and apparently prolobic, though its exact relation is obscure. 

Setae- There are eight setae per somite and they are widely paired. The formula, aa: $\underline{a b}: \underline{b c}: \underline{c d}=8: 2: 4: 6$ indicates approximately their relations. The arrangement of the setae is very uniform along the entire length of the body. The distance dd is about two-thirds the circumference. The setae are very indistinct. on 18 a and $\underline{b}$ are replaced by two modified penial setae which lie very close together just mesad at the male pore and in seta line $\underline{b}$. They lie so closely apposed that they appear to open into the same pore. The penial setae are relatively long and are curved distinctly at the tip. They are sculptured. A careful study was not made since it would have involved removal from the specimen and consequent damage.

Clitellum- (Fig. 11) The clitellum involves somites 13-20 and it is incomplete ventrally. It is not strongly thickened and is evident because of a slightly greater diameter of the worm and the darker color of these somites. The intersegmental grooves are somewhat deeper and the secondary grooves are more irregular than on other parts of the body. It covers the dorsal and lateral surface of the somites and the ventral margin is not at all abrupt.

Dorsal Pores- Dorsal pores are present posterior to the clitellum.

Male Pores- One pair of male pores are present on 18 about in line with $\underline{b}$. They open in the centre of a pair of large circular depressions. (Fig. 1l, g d ) As already stated, the penial setae are present just mesad of the male pore on each side and appear to open through this pore.

Oviducal Pores- One pair are present on somite 14 but are very indistinct. 

Spernathecal Pores- There is one pair of spermathecal pores in each of $7 / 8$ and $8 / 9$ in line with $b$. They are large and conspicnous.

Ventral Papillae- The ventral papillae are circular, paired elevations on $15 / 16,16 / 17,19 / 20$ and $20 / 21$. Those on $16 / 17$ are somewhat larger than the others. (Fig. $11, \nabla \mathrm{p}$ )

Internal characters.

Septa- The first distinct septum $4 / 5$ is very thin, $5 / 6$ and $12 / 13$ are a trifle thickened and $6 / 7-11 / 12$ are much thickened. Septum $17 / 18$ is pushed forward into 17 , and $18 / 19$ is pushed into 19 because of the large size of the prostate gland in 18 . Septa 7/816/I7 are connected with each other and the body wall by oblique muscular fibres.

Alimentary Pract- The alimentary tract begins with a large buccal sac. This is followed by the pharynx which fills the greater part of 2-4. The dorsal wall of the pharynx is very thick and muscular. The gizzard, located in 5, is large and muscular and fills practically all of the midale part of $5-1 / 28$ displacing the septa of these somites accordingly. The esophagus extends back to 19 fairly uniform throughout. A well developed typhlosole is present in the intestine. Calciferous glands are lacking.

Vascular system- A dorsal and a ventral vessel are present. The dorsal vessel is enlarged in 15-18. In each of somites $7-9$ is a pair of small hearts and in 10-13 a pair of large sacculated hearts which are very conspicuous. In the sections available for study, only the hearts in 13 are shown and they connect the ventral vessel with the mid dorsal part of a plexus of vessels imbedded in the alimentary canal. The plexus was continuous as far back as the sections were 

available for study. As far as studied, the vascular system very closely resembles that of Plutellus oregonensis described above. A more complete study was not made because of the lack of sectioned material.

\section{Excretory System- The excretory system is distinctly}

plectonephric. In the anterior and middle parts of the body there are present 7 pair of micronephridia in each somite. (Fig. 14 me $n$ ) These nephridia are all of about the same size and are tightly coiled into a cone shaped mass and are arranged in the somite in a definite order. The most ventral pair lie on the ventral floor in the anterior part of the somite. Lateral and a little posterior to these are the second pair, each succeeding pair lies a little more dorsal and posterior in the somite than the pair preceeding it. The seventh pair is frequently attached to the posterior septum of the somite very near the mid dorsal line. These nephridia are all attached to a narrow thin band of tissue (Fig. $14 \mathrm{n} \mathrm{c}$ ) which extends obliquely along the body wall from the anterior ventral to the posterior dorsal part.

A microscopic study of these nephridia reveals small nephridial ducts, one from each nephridium. The ducts of the different nephridia vary in length. The nephridial pores of each somite are very nearly in the transverse line which is in the plane passing through the most anterior ventral pair of nephridia and hence it is evident that the ducts from the posterior nephridia are much longer than those leading from the more ventral anterior ones. In the posterior part of the body there is in the ventral part of each somite a pair of large meganephridia and four pair of micro-nephridia. (Fig. $15 \mathrm{mg} n \mathrm{mc} n$ ). 

Spernaries and Sperm Ducts- One pair of spernaries and

large spermiducal funnels are located in the ventral pat of each of somites 10 and 1l. The spermaries extend freely into the somite from their attachment to the anterior ventral part of the septum. The sperm ducts of either side lie close together between the epithelium and muscle layer of the body wall in a latero-ventral position. They extend to 18 as two straight ducts. In 18 they ascend from the body wall into the body cavity and join the prostate gland. The two sperm ducts do not unite before entering the prostate; one enters directly and the second ascends to a higher point, loops back upon itself and enters the prostate duct very near the point at which the first enters. Prostate Glands- The prostate glands, of which there are but one pair, are large, much contorted, tubular organs filling the greater part of 18. They open to the exterior through a pair of long thick somewhat contorted ducts.

Sperm Sacs- A pair of small sperm sacs in each of somites 11 and 12 are attached to the anterior septa just below the alimentary tract.

Ovaries and Oviducts- One pair of small ovaries is located in the anterior ventral part of 13. The small oviducal funnels are attached to the posterior ventral surface of septum 13/14. A pair of short straight oviducts lead from the oviducal funnels to the external openings.

Spermathecae- One pair of spermatheare are present in each of somites 8 and 9. They are large elliptical organs lying obliquely in the somites. The spermathecal ducts are short, thick and without diverticula. 

Megascolides macelfreshi nov. spec.

Plate II. Figs. 13, 18.

Definition- Color, pale flesh tint with anterior ten somites more pronounced; clitellum fleshy orange, (Iiving specimen). Length $155 \mathrm{~mm}$. Diameter, 7-8 mm. Somites, 282. Prostomium, incomplete. Setae eight per somite; widely paired; anterior to clitellum, $\underline{a a}: \underline{a b}: \underline{b c}: \underline{c d}=10: 4: 5: 5$; posterior to clitellum, aa: $: \underline{a b}: \underline{b c}:$ $\underline{c d}=12: 3: 5: 5 ;$ dd is slightly more than one-half of the circumference Clitellum 13-21 (9 somites); incomplete ventrally. Papillae paired on $14 / 15-16 / 17,19 / 20$, and on 22 and 23 . Dorsal pores not visible. Male pores on 18; on large circular papillae. Oviducal pores on 14; mesad of a; conspicuous. Spermathecal pores on $7 / 8$, and $8 / 9$; conspicuous. Septa $7 / 8-10 / 11$ strongly thickened, 5/6, 6/7, $11 / 12$ and 12/13 somewhat thickened. Gizzard, small in 5. Nephridia plectonephric; one pair of meganephridia and several micronephridia in posterior somites. Spermaries, one pair in each of somites 10 and 11. Sperm ducts extend to 18 , unite before entering prostate duct. Sperm sacs, one pair in each of somites 11 and 12 . Ovaries, one pair in 13. Spermathecae, one pair in each of somites 8 and 9.

The description is based upon a single specimen in the collection of Professor Frank Smith which was received from Mr. F. M. McElfresh, January 1903, and was collected from Salem, Oregon.

External Characters.

The color of the living specimen was a pale flesh tint, more pronounced on the anterior 10 somites. The worm was unpigmented and the internal organs were faintly visible. The clitellum was fleshy orange in color and definitely distinct. The surface adjacent to the spermathecal pores on $7 / 8$ and $8 / 9$ was faintly brownish. The 

length of the worm when relaxed was about $300 \mathrm{~mm}$.

The specimen after preservation in alcohol measures $155 \mathrm{mrn}$. in length and $7-8 \mathrm{~mm}$. in diameter. There are 282 somites in the body and they are triannulate back to 22. The prostomium is small and incomplete giving an indication of the prolobic condition.

Setae- There are eight setae per somite, widely paired. Anterior to the clitellum $\underline{a}: \underline{a b}: \underline{b c}: \underline{c d}=10: 4: 5: 5$. Posterior to the clitellum $\underline{a a}: \underline{a b}: \underline{b c}: \underline{c d}=12: 3: 5: 5$. The distance dd a little over onehalf the circumference. On 18 there is no superficial evidence of a and $\underline{b}$. Sections reveal the presence of a single penial seta imbedded in a large muscular sac located just mesad of the opening of the prostate gland. Indications of a muscular sac just laterad of the other are obvious although no seta could be found. The penial setae are rather short, straight and somewhat soulptured. Setae $\underline{c}$ and $\underline{d}$ retain their normal positions on 18 .

Clitellum- (Fig. 13) The clitellum is considerably thickened and involves somites 13-21. It is incomplete ventrally, the ventral margins being approximately half way between the seta lines $\underline{c}$ and $\underline{d}$. The surface is deeply grooved showing distinctly the triannulate divisions of the somites.

Male Pores- One pair of male pores is present on somite 18, each of the pores being in the center of a large circular papiliae. (Fig. 13, gp.)

Oviducal Pores- The pair of oviducal pores is on somite 14. They are conspicuous and lie in a position a little mesad of seta on an elongate elliptical elevation which extends across the ventral surface of the somite reaching as far as $\underline{c}$ on either side. (Fig. 13, op.) 

Spermathecal Pores- One pair of spermathecal pores on each of somites $7 / 8$ and $8 / 9$ are conspicuous openings in the seta line $\underline{b}$ and each is surrounded by two lip-like elevations.

Ventral Papillae- Paired ventral papillae are located in 14/15, 15/16, 16/17 and 19/20. They are circular and uniform in size shape and position. (Fig. $13 \mathrm{vp}$. ) A pair of oval papillae is present on each of somites 22 and 23 in the intervals between a and c.

\section{Internal Characters.}

Septa- The first distinct septum is $5 / 6$ which is very thin. $6 / 7$ and $11 / 12$ are somewhat thickened and $7 / 8-10 / 11$ are much thickened. Septum $17 / 18$ is pushed forward into 17 and $18 / 19-20 / 21$ are pushed into 21 by the large prostate gland in 18. Septa $7 / 8-14 / 15$ are connected by longitudinal fibres.

Alimentary Tract- There is an eversible buccal sac at the anterior end of the alimentary tract, followed by the pharynx which has a thick muscular dorsal wall. The gizzard is muscular and relatively small. It lies in 5 and fills 6 as well, pushing the septa $5 / 6$ and $6 / 7$ back into somite 7 . The esophagus extends back to 19 and is somewhat enlarged in 10 and 11 . In 18 it enlarges and joins the intestine in 19. A large typhlosole is present in the intestine. Calciferous glands are lacking.

Vascular System- The vascular system could not be worked out in detail because of the lack of material. The dorsal vessel is single and is greatly enlarged in 15-18. The ventral vessel is located just ventrad of the intestine. In each somite 7,8 and 9 is found a pair of small hearts and in 10-13 a pair of hearts which are somewhat larger. 

Excretory system- The excretory system has the condition typical in Megascolides, there being several micronephridia in the somites in the anterior part of the body and besides micronephridia one pair of meganephridia in each of the posterior somites. It is rather difficult to determine the exact number of nephridia and pores present but there are at least five pair and perhaps more.

\section{Spermaries and Sperm Ducts- There is a pair of spermaries} in each of somites 10 and 11 which project freely into these somites from their attachment to the ventral part of the anterior septum. The pair of spermiducal funnels in each of somites 10 and 11 are large and fill a considerable part of the posterior ventral portion of these somites. The two sperm ducts of either side lie close together and parallel just beneath the inner epithelial tissue of the body wal1. They lie in a latero-ventral position. In 18 they become free from the body wall and extend dorsally and then ventrally forming a loop and then join the outer, lower part of the prostate gland along which they extend for some distance gradually penetrating deeper into the tissues of the wall. The two ducts which have had a parallel course finally unite into one duct just before entering the prostate gland.

Prostate Glands- The prostate glands are a pair of large tubular contorted organs which fill the dorsal and lateral portion of somite 18, and displacing the septa encroach extensively on 17 and 19. They open to the exterior through a pair of long, tubular. ducts which are joined by the sperm ducts as described above.

Sperm Sacs- There is a pair of small sperm sacs in each of somites 11 and 12 attached to the anterior septa of the somites in which they lie. They are slightly ventrad of the alimentary canal. 

Ovaries- There is a pair of small racemose ovaries in the anterior ventral part of somite 13. The oviducts open through conspicuous pores on somite 14 .

Spermathecae- (Fig. 18) There is a pair of spermathecae in each of somites 8 and 9 , those in 8 being only about one-half as large as those in 9. They are bluntly elliptical in shape. Spermathecal diverticula are lacking and each spermatheca opens to the exterior through a short, thick, straight duct.

\section{Megascolides americanus Smith.}

$$
\text { Plate II. Figs. 12, } 16 .
$$

Definition- Length, 180-190 mm. Diameter, 6-7 mm. Somites, average (four specimens) 226; extremes, 190-240. Prostomium, prolobic. Setae, eight per somite; widely paired; anterior to clitellum $\underline{a a}: \underline{a b}: \underline{b c}: \underline{c d}=10: 2: 8: 4$; posterior to clitellum, aa: $\underline{a b}: \underline{b c}: \underline{d c}=12: 3: 7:$ 4; d is about $2 / 3$ of circumference; penial setae, present. Clitellum incomplete on 13-1/n 23. Median circular papillae on 14/15, 15/16, 16/17, paired papillae on 19/20, 20/21. Median papillae were lacking on one specimen. Dorsal pores, posterior to clitellum. ivale pores paired on 18 on an elliptical elevation which extends across the ventral surface of the somite. Oviducal pores on 14, very conspicuous. Spermathecal pores not visible. Septa, 5/6 and 12/13 somewhat thickened. 6/7-11/12 strongly thickened. Gizzard, large in 5. Plectonephric; one pair of meganephridia and 7 pair of micronephridia in posterior somites. Spermaries, one pair in each of somites 10 and 11. Sperm ducts of either side join in 16, extend to 18, and unite with the prostate duct. Sperm sacs, one pair, in each of 11 and 12. Ovaries, one pair in 13. Spermathecae one pair in each of somites 8 and 9 . 

The determination of the relationships of $\underline{M}$. cascadensis and M. macelfreshi to that of M. americanus Smith has involved a reexamination of the specimens on which the description of the latter species was based, and has resulted in some additional information Which is here presented.

Somites 1-6 are biannulate and 7-12 are triannulate. The clitellum is but slightly thickened and shows almost no traces of external separation into somites. (Fig. 12) There are four pair of setae per somite, $a b$ being less than cd. Anterior to the clitellum $\underline{a a}: \underline{a b}: \underline{b c}: \underline{c d}=10: 2: 8: 4$. Posterior to the clitellum $a \mathrm{a}: \underline{a b}: \underline{b c}: \underline{c d}=$ 12:3:7:4. The distance da is about two-thirds of the circumference. The penial setae are straight and sculptured. There is a pair of male pores on 18 in the middle part of the somite. They open on an elongate elliptical elevation which extends across the ventral surface of the somite to a point midway between $\underline{b}$ and $\underline{c}$ of either side. (Fig. 12, gp.) The elevation encroaches anteriorly on 17 and posteriorly on 19. The spermathecal pores are not visible, probably due to the immaturity of the specimens.

The first distinct septum $4 / 5$ is very thin; $6 / 7-11 / 12$ are strongly thickened. A single dorsal vessel and a ventral vessel are present. There is in each of somites $7-9$ a pair of small hearts and in each of somites 10-13 a pair of large hearts of which 12 and 13 are the largest. There are seven pair of micronephridia on the anterior somites and besides these there is present an additional pair of meganephridia in each somite in the posterior part of the body. (Fig. 16, mg $n$, me $n$ ) The spermathecae are very small, elliptical organs lying obliquely in 8 and 9 . Diverticula are lacking.. 

Comparison of Species.

The only species of Megascolides which is sufficiently similar to the new ones just described to require a comparison is M. americanus Smith (1897: 202 - 204) from Pullman, Washington. A tabular arrangement of the important characters follows:

Characters Megascolides

americanus

Length $\quad 180-190 \mathrm{~mm}$.

Diameter $6-7 \mathrm{~mm}$.

Somites

226, 1-6 biannuate,

7-12 triannulate

M. cascadensis

M. macelfreshi

$185 \mathrm{~mm}$.

$155 \mathrm{~mm}$.

5-7 mm.

$7-8 \mathrm{~mm}$.

275, 1-5 biannu-

282, 1-22 trian-

late, 6-12 triannu- nulate.

late.

clitellum

13-1/n23, incom-

plete ventrally.

Setae

Widely paired;

anterior to clitel-

$\operatorname{lum} a a: a b: b c: c d=$

$10: 2: 8: 4$; posterior

to clitellum

$a a: a b: b c: c d=$

$12: 3: 7: 4 ;$ dd is

about $2 / 3$ the cir-

cumference.

Ponial

Short and straight,

setae

Dorsal

13-20, incomplete

ventrally.

Midely paired;

very uniform on

entire length of

body.

$\underline{a a}: \underline{a b}: \underline{b c}:$

$\underline{\mathrm{cd}}=8: 2: 6: 4: \underline{\mathrm{dd}}$

is about $2 / 3$ the

circumference.

$$
\text { circumference. }
$$

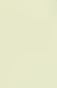



Characters Magascolides

americanus

pores clitellum

Nale pores an elliptical elevation. (Fig. 12 depression. (Fig. gop.)

Oviducal pores

Paired on 14 very indistinct.

\section{1. gd.)}

Paired on 14. indistinct.

\section{clitellum}

One pair on 18

One pair on 18 each in a circular each on a circular papilla. (Fig. 13 gp.)

Paired on 14 , distinct. on an elliptical

elevation.

Spermathec- one pair, indisal pores tinct.

One pair, large, conspicuous.

One pair, conspicuous openings, surrounded by two Iip-Iike el-

Ventral Median papillae

Paired circular

evations. Paired papillae on $15 / 16$, circular papillae $16 / 17,19 / 20$. 20/21. (Fig. 11, vp.) on $14 / 15,15 / 16$, in $19 / 20$ and 20/21. Median papillae lacking in one specimen. (Fig. 12, vp.)

Septa $4 / 5$ first distinct septum, 6/7-11/12 strongIy thickened, 5/6 $4 / 5$ first distinct septum 6/7-1I/12 tinct septum. are strongly thick- $7 / 8-10 / 11$ are ened, $5 / 6$ and $12 /$ $12 / 13$ are somewhet 13 are somewhat strongly thickened. $6 / 7$ and 



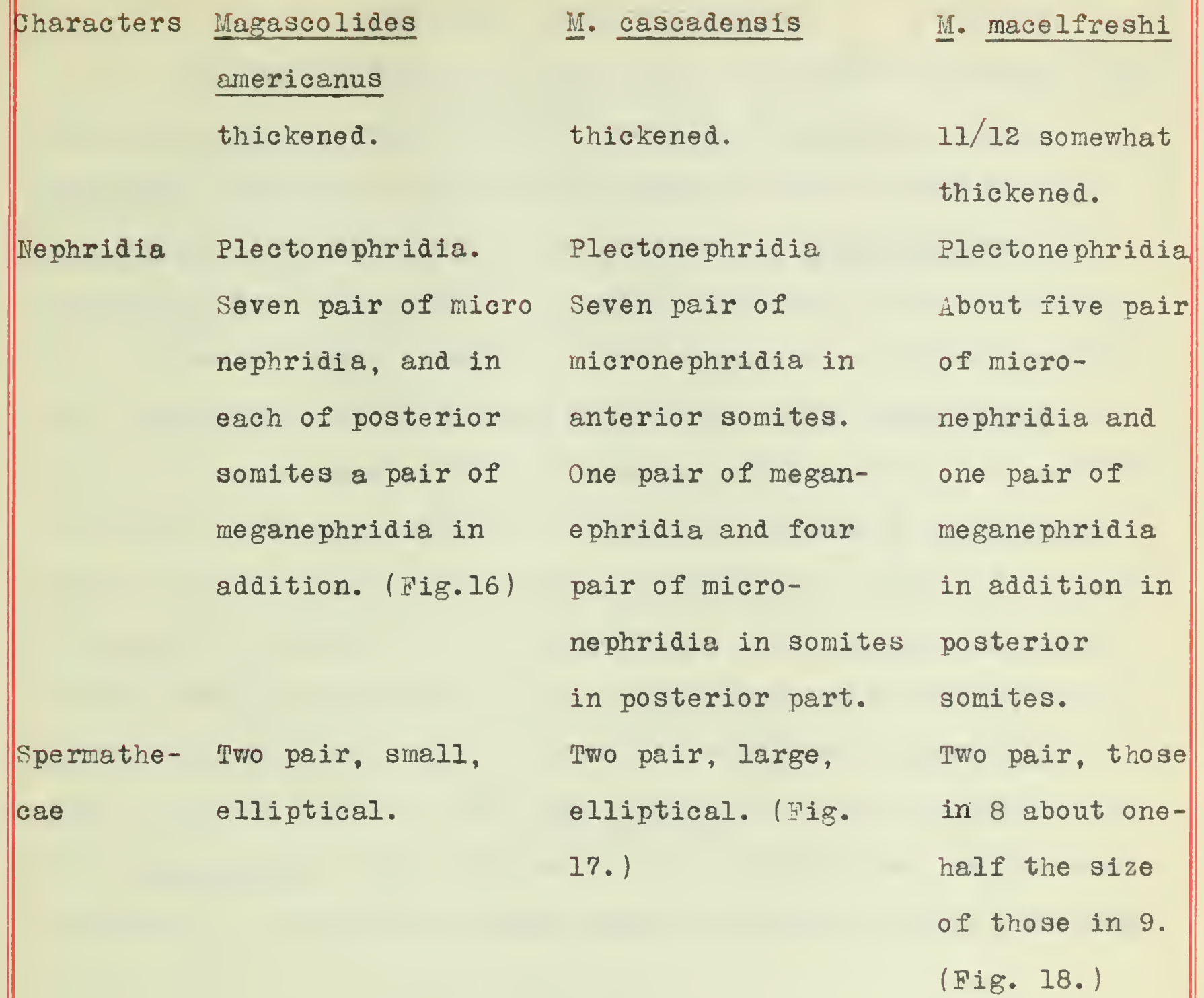



Discussion of Relationships.

An examination of the principal differences tabulated above indicates a closer relationship between $\mathbb{M}$. cascadensis and $\mathbb{M}$. americanus than that which exists between either of them and $M$. macelfreshi. The main differences between $\underline{M}$ americanus and $\underline{M}$. cascadensis are: The number of somites included in the clitellum; shape of penial setae; position of male pores on a genital papilla in M. americanus and in genital depressions in M. cascadensis: number and position of ventral papillae; and the number of nephridia

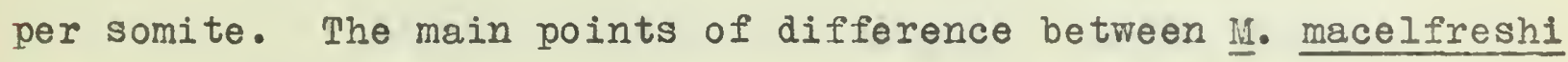
and the two forns just previously compared are; length of clitellum intermediate between the other two forms; setae moremarly equally paired; penial setae similar to $\underline{M}$. americanus and different from $\underline{M}$. cascadensis; genital pores on a pair of papillae in contrast to a single elongate papillae in $M$. americanus and a pair of depressions in M. cascadensis; shape and position of spermathecae; number and arrangement of ventral papillae; number of septa greatly thickened; and the number of nephridia per somite.

A sufficient number of differences exist in the cascade and Salem worms when compared with each other and with $M$. americanus to require the recognition of a distinct species for each of them.

The three new species described in this paper belong to the family Megascolecidae and to the genera Plutellus and wegascolides which are separated from each other chiefly through the character of the nephridia which are meganephric in Plutellus and plectonephric in Megascolides. The remaining characters are very similar in the two genera. 



\section{References to Iiterature.}

Eisen, G.

1894. On California Eudrilidae. Mem. Calif.

Acad. Sci., 2: 21-62. $18 \mathrm{pl}$.

1900. Researches in American Oligochaeta, with Especial Reference to those of the Pacific Coast and Adjacent Islands. Proc. Calif. Acad. Sci. 2:85-276. $10 \mathrm{pl}$.

Michaelsen, W.

1900. Oligochaeta. Das Tierreich, 10 Iief. XXIX + 575 pp., 13 fig. Berlin.

Smith, F.

1897. Upon an Undescribed Species of hegascolides from the United States. Am. Nat. 31: 202204. 



\section{Explanation of Plates. \\ Abbreviations.}

am ampulla

cl clitellum

c $\nabla$ connecting vessel

d $h$ dorsal heart

d i dorso-intestinal branches

d $\nabla$ dorsal vessel

e s d evagination of spermathecal diverticulum

g a genital depression

g p genital pepilla

i h intestinal hearts

i h d connective between intestinal hearts and dorsal vessel

i p intestinal plexus

e $v$ p longitudinal vessel of plexus

It $v$ lateral vessel

me $n$ micronephridia

mg $n$ meganephridia

n c tissue band connecting nephridia

- p oviducal papilla

s di spermathecal diverticulum

s du spermathecal duct

$t \quad v$ p transverse vessel of plexus

$\checkmark$ p ventral papilia

$v t$ ventro-tegumentary

$\nabla$ ventral vessel 



\section{Explanation of Plates. \\ Plate I.}

Fig. 1. Penial seta of Plutellus oregonensis.

Fig. 2. Penial seta of $\underline{P}$. marmoratus.

Fig. 3. Penial seta of $\underline{\underline{p}}$. collinus.

\section{Plutellus oregonensis.}

Fig. 4. Schematic diagram of transverse section of somite 9 to show parts of circulatory system.

Fig. 5. Schematic diagram of transverse section in somite 11 to show parts of circulatory system.

Fig. 6. Schematic diagram of circulatory system in somites $5-15$.

Fig. 7. Anterior view of spermatheca.

Fig. 8. Iateral view of spermatheca.

Fig. 9. Spermatheca of somite 8 in sagittal section of worm.

Fig. 10. Spermatheca of somite 9 in transverse section of worm.

The vertical lines beside the figures $7-10$ represent $0.1 \mathrm{~mm}$. 



\section{Explanation of Plates. \\ Plate II.}

Fig. 11. Clitellar somites of ilegascolides cascadenses, ventral view.

포. 12. Clitellar somites of M. americanus, ventral view.

Fig. 13. Clitellar somites of M. macelfreshi, ventral view.

Fig. 14. Somites from anterior part of M. cascadensis to show nephridia.

Fig. 15. Somites from posterior part of M. cascadensis to show nephridia.

Fig. 16. Somites from posterior part of $M$. americanus to show nephridia.

Fig. 17. Spermatheca of M. cascadensis.

Fig. 18. Spermatheca of $\mathrm{M}$. macelfreshi.

The ventral lines beside the figures represent $2 \mathrm{~mm}$. 



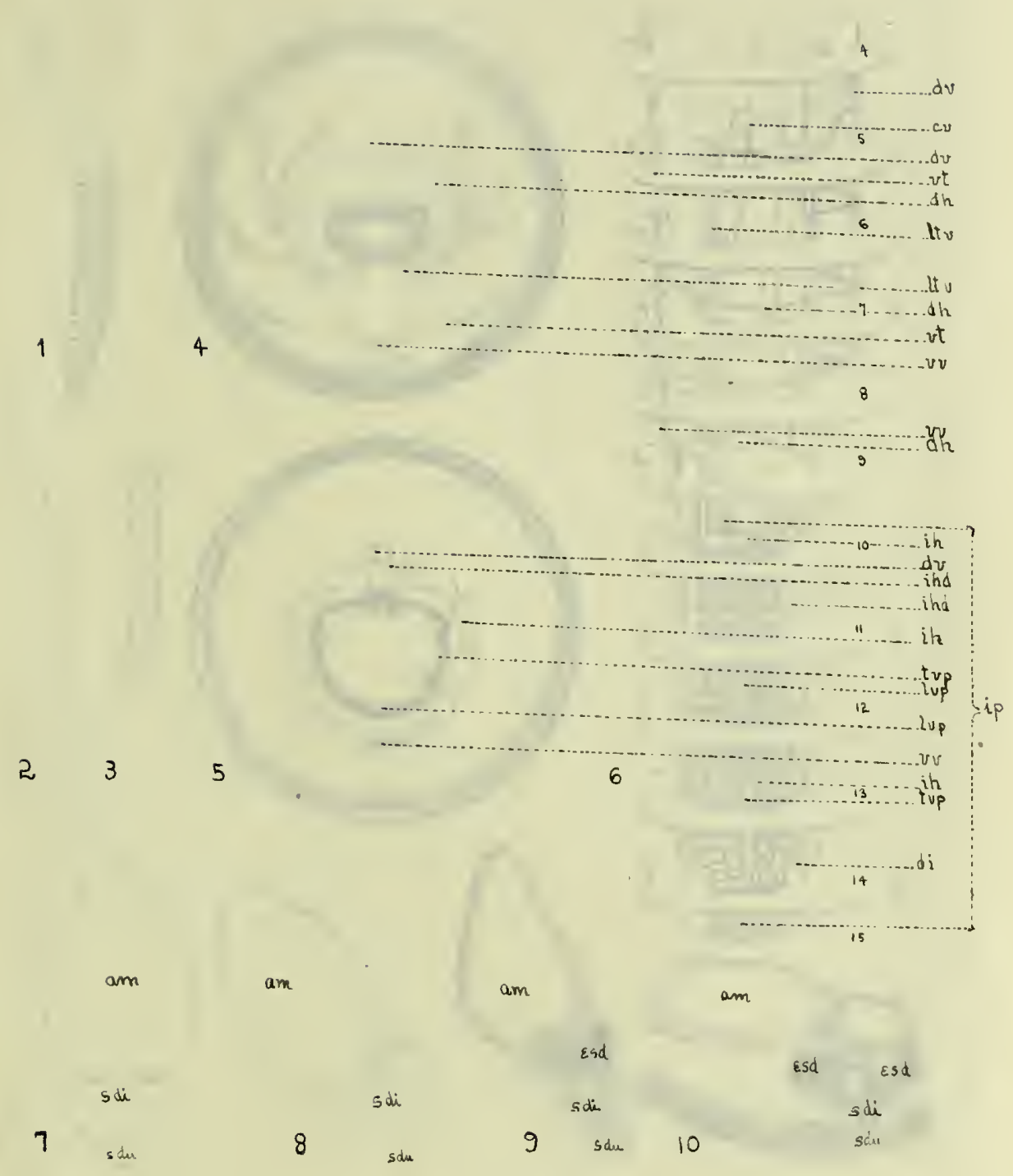



Plate I.

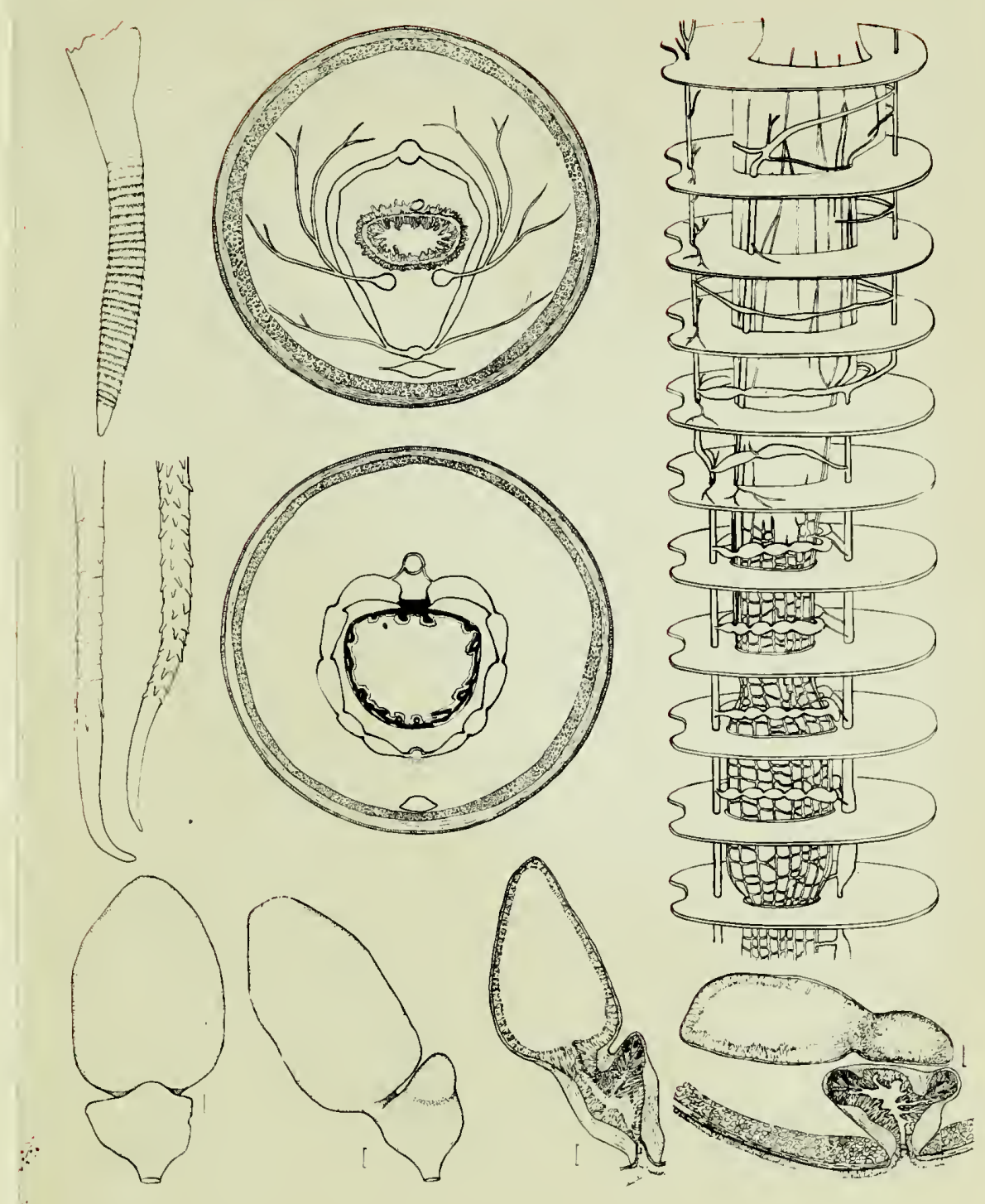





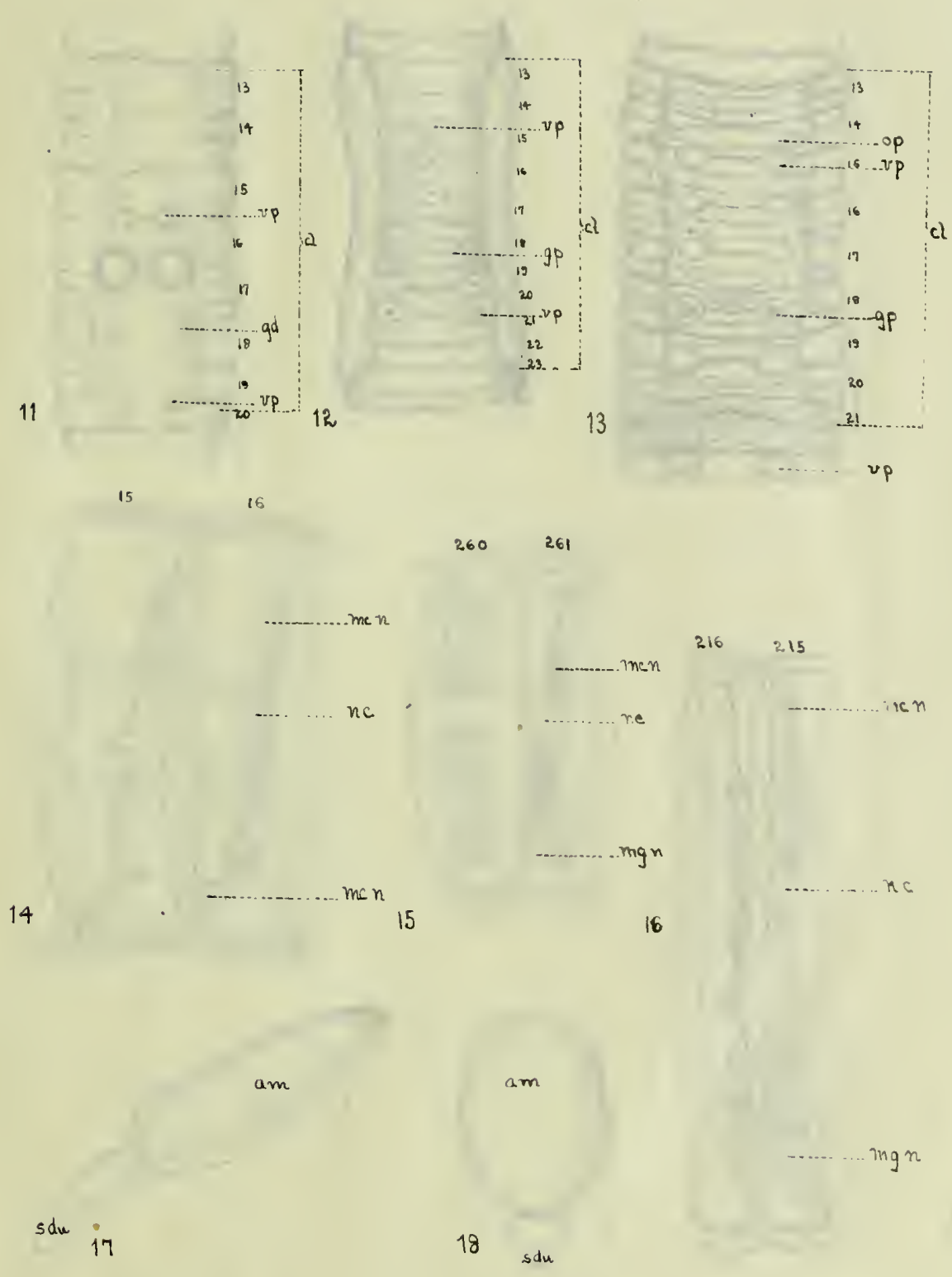





\section{PIate II.}
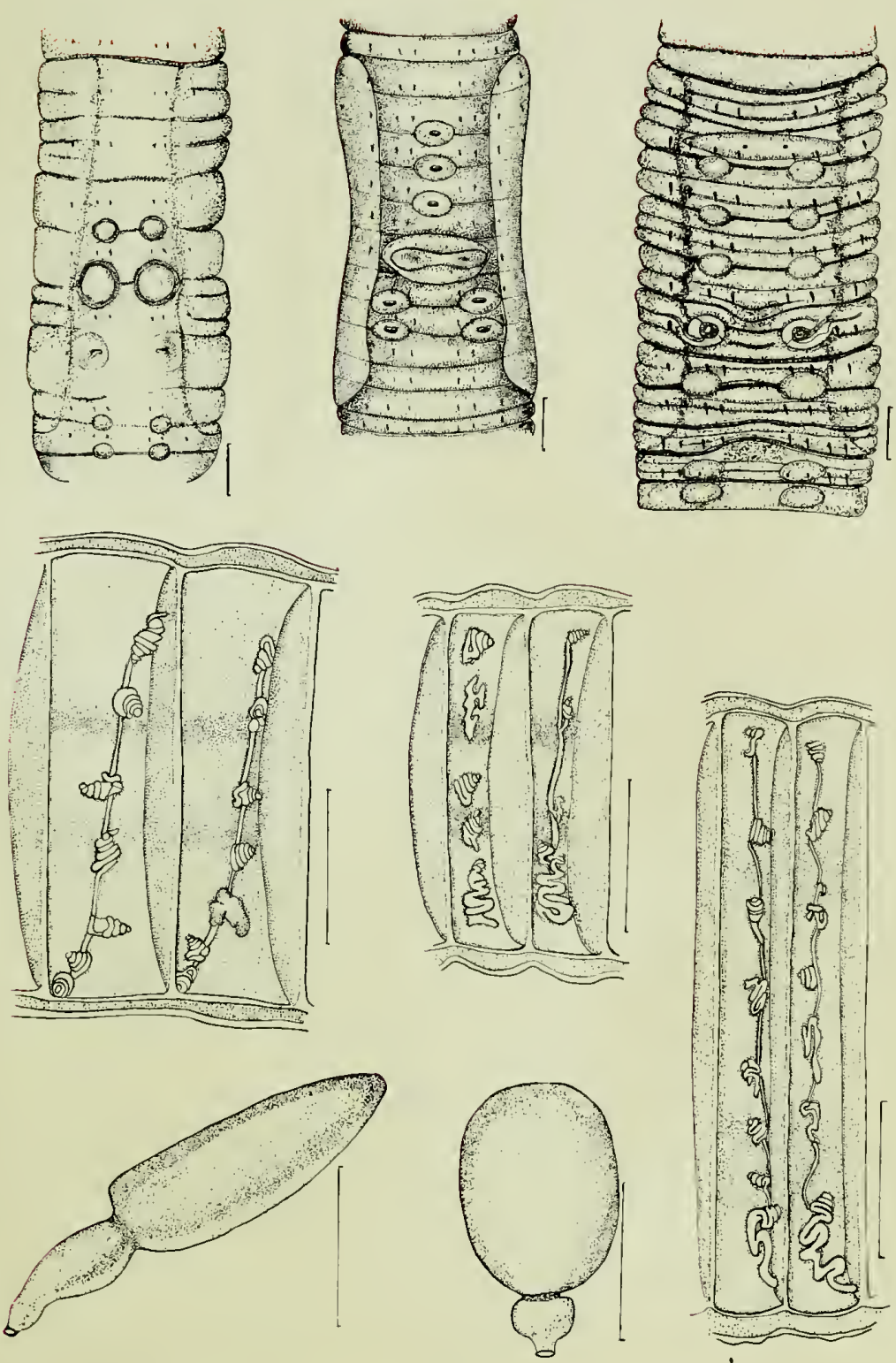



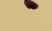


